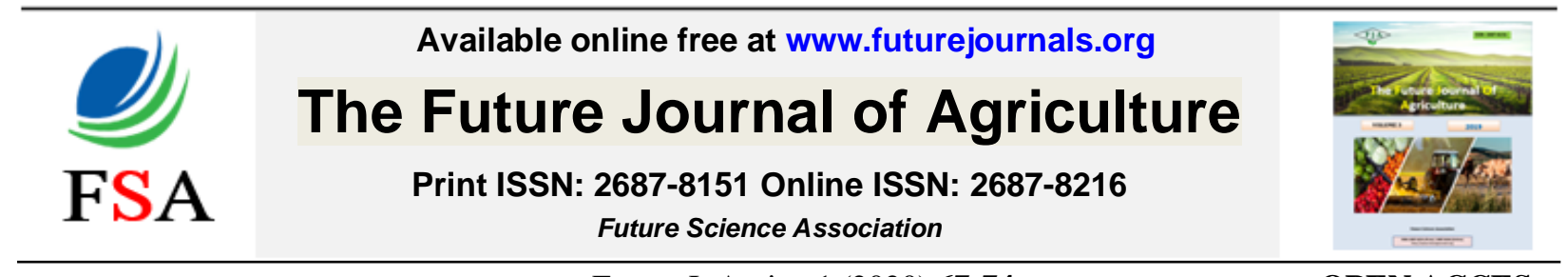

Future J. Agric., 1 (2020) 67-74

OPEN ACCES

DOI: 10.37229/fsa.fja.2020.03.28

\title{
STUDY ON THE RESPONSE OF THE SAFARI POTATO VARIETY TO SPRAYING WITH THE NUTRIENT SOLUTION HORTIPHYTE AND THE SEAWEED EXTRACT STYMULANT FORTE
}

\author{
Ragheed H. Al-Sultan; Khaleda A. Omar and Wahida A. Ahmed \\ Hort. \& Landscape design Dept., College of Agriculture and Forestry - University of Mosul, Iraq. \\ *Corresponding author: ragheed_1975@yahoo.comＲeceived: 25 Feb. 2020 ; Accepted: 28 March 2020
}

\begin{abstract}
An experiment was carried out in vegetable fields, Department of Horticulture and Gardening, College of Agriculture and Forestry, Mosul University for the spring season 2018. To find out the effect of foliar feeding of a seaweed extract (Stymulant forte) in concentrations of $(0,3$ and 6$) \mathrm{g}^{-} \mathrm{L}^{-1}$ and Hortiphyte nutrient solution in concentrations $(0,2$ and 4$) \mathrm{ml}^{-1} \mathrm{~L}^{-1}$ on the potato crop class A (Safari). The experiment was carried out with 9 factor treatments according to the Randomized complete block design (RCBD), with three replications. The results of the studied treatments were tested according to the polynomial Duncan test at a probability level of 0.05 . The results showed the superiority of the treatment of spraying seaweed extract at concentration $6 \mathrm{~g}$. $\mathrm{L}^{-1}$ was significant, given the highest significant values for average stem length and number of aerial stem. plant ${ }^{-1}$, and the percentage of dry matter for the plant $\%$, while spray treatment was superior to 3 g. $\mathrm{L}^{-1}$ was significant in the leaf area index, treatment of spraying feeding solution in two or four ml concentrations. L-1 was significant at average stem length $(\mathrm{cm})$ and number of aerial stem. plant ${ }^{-1}$, with an increase of (5.10 and 15.35\%), respectively; compared to the comparison treatment. The two characteristics of chlorophyll and the percentage of dry matter per plant were not different from the comparison treatment. As for the results of the total yield, it was given the treatment of spraying the seaweed extract at a concentration of $6 \mathrm{~g}$. $\mathrm{L}^{-1}$ is the most significant value for the number of tubers. Plant ${ }^{-1}$, average weight of tuber $(\mathrm{kg})$, yield of one plant $(\mathrm{kg})$, percentage of dry matter for tubers\%, and production rate per area (tons. ha-1) compared to the rest of the treatments, and reached (13.111 tuber. Plant ${ }^{-1}, 0.126 \mathrm{~kg}, 1.63 \mathrm{~kg}, 16.127 \%, 87.390 \mathrm{ton}^{\mathrm{ha}^{-1}}$ ), respectively. The treatment of spraying the nutrient solution affected the 2 or $4 \mathrm{~mL}$ concentrations. 1 liter $^{-1}$ morally by giving the highest significant values for the average weight of the tuber, the yield of one plant and the percentage of dry matter for tubers and total production per area compared to the no-spray treatment, and with an increase of $11.11 \mathrm{~kg}, 11.68 \mathrm{~kg}, 7.43 \%, 11.54$ tons. $\mathrm{ha}^{-1}$ ), respectively. It did not differ from the comparison treatment in terms of the number of tubers. plant ${ }^{-1}$.
\end{abstract}

Key words: Potato, seaweed extract, Hortiphyte nutrient, vegetative growth, yield, fertilization.

\section{INTRODUCTION}

Potato crop (Solanum tuberosum L.) is one of Solanaceae family, it is an important vegetable crop in many countries, including the Arab world. It is ranked fourth economically after wheat, rice, and yellow corn (Taha, 2007), and forms part of the daily food for more than $75-90 \%$ Elia and Sanitaria (1997). It is an important source of energy because it contains carbohydrates, (Hassan, 1999). The total area planted with this crop in Iraq is about 7825 hectares in 1989, and increased to 33065 hectares in 1997 (Annual Statistical group, 1998). However, the production has decreased to 3,942 hectares in 2004 , with a productivity of 630 thousand tons, (Ministry of Agriculture, 2005).

Nevertheless, the cultivated areas increased to 33,520 hectares in 2008 with a productivity of 598 thousand tons (FAO, 2008), and the cultivated area reached 8,160 hectares in Nineveh Governorate in 2009 (Nineveh Agricultural Directorate / planning and followup). Continuously, the cultivated area increased 
to 9,610 hectares with a production of 266.794 tons for the year 2017 (FAO, 2019), the reason for the low productivity in Iraq is due to many reasons, including the lack of interest in agricultural operations such as fertilization and pest control, the lack of adoption of modern agricultural methods, and the lack of good seed for agriculture, which is an important factor in increasing Productivity (Matloob et al., 1989).

Potato crop production is affected by many factors, the most important is using appropriate variety for the region with good specifications. High productivity affected by the genetic nature of a certain class which influence the quantity and quality of the production (Potato cultivation technology, 2005), as well as climatic factors (weather factors + soil factors). None of the less, seaweed extracts and nutrient solutions on a large scale in plant nutrition are used recently. It contains natural growth regulators and multiple nutrients in addition to amino acids and organic materials needed for plant growth and production. It works to balance the elements supplementary food within the plant because of their effectiveness and easily absorbed by the plant when used paper nutrition (Verkeij, 1992; Jensen, 2004 and Strik et al., 2004).

In addition to being natural materials that leave no impact on humans and the environment, and have the ability to stimulate growth and development and increase its resistance to environmental stresses. Moreover, it increases plant resistance to diseases and insects (Abo-Arab et al., 1998).

Therefore, implementing some field treatments including the use of spray with nutrient (Hortiphyte) with spraying seaweed extract (Stymulant) have been used in this experiment for:

1. Study the role and effect of foliar feeding with seaweed extracts and nutrient solutions individually or in combination on potato growth and production, both quantity and quality.

2. Choose the optimal fertilizer treatment for potato crop to enhance the production.

\section{MATERIALS AND METHODS}

The experiment was carried out in the vegetable fields, Department of Horticulture and Gardening, College of Agriculture and Forestry, Mosul University for the spring season 2018. The aim of the study, therefore, is to find out the effect of foliar feeding with seaweed extract (Stymulant forte); it is a Spanish production under the name of Meristem. It contains 100\% Ascoophyllum nodosum fungi, amino acids, organic materials, oxins, cytokine and gibberlin, as well to potassium oxide $19 \% \mathrm{~W} / \mathrm{W}$ and free amino acids $4 / 4 \% \mathrm{~W} / \mathrm{W}$ in concentrations $(0,3$ and 6$)$ g. $\mathrm{L}^{-1}$.

The Hortiphyte nutrient solution is a Dutch company production named SATCO. It contains NPK at a concentration of 0,20 and $3 \%$ with two elements (Mn 2\% and $\mathrm{Zn} \mathrm{3 \%}$ ) in concentrations $\left(0,2\right.$ and 4) $\mathrm{ml}^{\text {. liter }}{ }^{-1}$. They were applied to a potato crop (Safari) of Dutch varieties. This type however, is a result of Obelix $\times$ Amadeus cross-breeding, which is early in production and highly productive.

The experiment was carried out according to randomized complete block design (RCBD) with nine factorial factors and in three replicates.

The tubers were planted on lines, heading from north to south. The experimental unit included Two meters length and width of $75 \mathrm{~cm}$ and the experimental unit area was $3 \mathrm{~m}$ by $2 \mathrm{~m}$. The compound fertilizer K: P: N (18: 48: 0) \% added at a rate of $600 \mathrm{~kg} \cdot \mathrm{ha}^{-1}$ for all treatments (Al-Ubaidi, 2005). The first batch was at the appearance of plant leaves. The second batch was after 15 days (upon completion of the plant leaves). The addition was scattering around plants $(10 \mathrm{~cm}$ from the plant $)$ in the upper third of the furrow. Potassium sulphate $\mathrm{K}_{2} \mathrm{O}(50 \%)$ was added at $5 \mathrm{~g}$. liter $^{-1}$ by spraying on two leaves in two batches, the first at the flowering stage, i.e. when the tubers originated, and the second batch when the volume of tubers increased, i.e. 15 days after the first spray. Planting was starting on 25/2/2018 using tubers with a diameter of $50-55 \mathrm{~mm}$ as seed for planting (Daoud and Kassem, 2003), the tubers were manually planted at a distance of 25 $\mathrm{cm}$ and a depth of $10-12 \mathrm{~cm}$. The plants were sprayed with nutrient and seaweed extract a week after the full appearance of leaves and repeated 3 times and 15 days between sprinkles to another.

\section{The studied characteristics}

Eight plants were randomly selected for each experimental unit, and the following measurements were taken: 
1- Number of main aerial stems (stem. Plant ${ }^{-1}$ ): Randomly taken according to the average number of main formed stems.

2- Plant height $(\mathrm{cm})$ : The average height of the plant was measured randomly by measuring the lengths of the main stems in a single plant from the soil surface level to the growing top, according to the rate.

3- The total leafy area of the plant $(\mathrm{d} 2 \mathrm{~cm}$. Plant $\left.^{-1}\right)$ : The leafy area was calculated by weight method after 70 days of planting (in the stage of increasing the volume of tubers). Discs with an area of $1 \mathrm{~cm} 2$ were taken at a rate of 20 discs of whole plant. leaves were randomly taken by a sharp cylinder with a diameter of 1 $\mathrm{cm}$. Discs and leaves were dried in oven at a degree of $68-70{ }^{\circ} \mathrm{C}$ for 48 hours until the weight is stable. The area of one leaf is calculated in a proportionate and proportionate way based on the dry weight of the discs and leaves. The area of one leaf is multiplied by the dry weight of the leaves of one plant to calculate the leafy area of the plant.

4- Measuring the percentage of chlorophyll in leaves: The percentage of chlorophyll in potato plant leaves was estimated by the Chlorophyll Meter type SPAD -502 by taking a reading from 20 plants per experimental unit and taking the rate (Minnotti et al., 1994), and was measured in units of SPAD as mentioned in (Jemison and Williams, 2006).

5- The percentage of dry matter: Five tubers have randomly taken from each experimental unit and for all replicates immediately after the harvest and well washed, then left at room temperature to dry the water on its surface. The tubers were cut into slices at a weight of 100 grams uniformly for all treatments, and then dried in the oven at a temperature of $70-72{ }^{\circ} \mathrm{C}$. for 72 hours until the weight is fixed. Then it weighed dry. The percentage of dry matter was calculated in tubers.

6-Tuber weight rate (g): Calculated by dividing the quotient of the experimental unit by the number of tubers produced. This is after excluding the smaller weight tubers of $(25 \mathrm{~g})$ and for the three replicates.

7- Average yield of one plant (g. plant ${ }^{-1}$ ): Calculate by dividing the total number of tubers by the number of experimental unit plants, this is after excluding the smaller weight tubers of $(25 \mathrm{~g})$ and for the three replicates.
8- Total quotient (ton. $\mathrm{ha}^{-1}$ ): Calculate from the sum of one plant, the sum of the experimental unit, and the hectare.

\section{RESULTS AND DISCUSSION}

\section{Vegetative growth characteristics}

It is evident from the results of Table (1) that spraying the seaweed extract significantly affected most characteristics of vegetative growth, as the treatment of spraying was superior to $6 \mathrm{~g}$. $\mathrm{L}^{-1}$ gives the highest significant values in average stem length $(\mathrm{cm})$ and number of aerial stems. plant ${ }^{-1}$ and leaf content of chlorophyll (SPAD) and the percentage of dry matter for the plant $\%$ that reached $(90.06 \mathrm{~cm}$, 4.727 stem. plant $^{-1}$, 52.311 SPAD, 12.006\%) respectively compared to the non-spray treatment. spray treatment by $3 \mathrm{~g}$. Liter ${ }^{-1}$ was outperformed significantly compared to the rest of the treatments in foliar area and reached $\left(166.89 \mathrm{dm}^{2}\right)$. As for the effect of the nutrient solution, it is evident from the same table that the two spray treatments exceed the 2 or $4 \mathrm{ml}$ concentrations. $\mathrm{L}^{-1}$ was significant in the average stem length and number of aerial stem. plant $^{-1}$, with an increase of (5.10 and $\left.15.35 \%\right)$, respectively, compared to the comparison treatment. Whereas, both concentrations did not differ significantly from the comparison treatment in the two characteristics of chlorophyll and the percentage of plant dry matter\%, and the leaf area decreased when spraying with the same two concentrations. From the interaction factors between seaweed extract and nutrient solution, it is clear that spraying seaweed extract at a concentration of 6 g. $\mathrm{L}^{-1}$ with $4 \mathrm{ml}$. $\mathrm{L}^{-1}$ nutrient solution was significantly superior by giving the highest average length of the stem reached $(82.33 \mathrm{~cm})$ compared to the rest of the treatments and did not differ with the treatment of spraying with 3 g. $\mathrm{L}^{-1}$ seaweed extract; along with the same concentration of nutrient solution or with the treatment of spraying seaweed extract with $6 \mathrm{~g}$. $\mathrm{L}^{-1}$ without spraying nutrient solution.

The lowest average length of stem was in the treatment of non-spraying feeder with spraying seaweed extract at $3 \mathrm{~g} . \mathrm{L}^{-1}$ that reached $(68.00 \mathrm{~cm})$. The average number of aerial stems of the plant increased significantly when sprayed by $6 \mathrm{~g}$. L $\mathrm{L}^{-1}$ seaweed extract with $2 \mathrm{ml}$. Liter $^{-1}$ feed solution and reached $(5.667$ stem. plant-1), compared to most interference 
treatments except spray treatment with $2 \mathrm{ml}$. Liter $^{-1}$ feeder solution with no spray in seaweed extract. The lowest average number of stems was with the treatment of non-spraying both solutions and results have reached (3,500 stem. plant $\left.^{-1}\right)$, while the leaf area increased significantly when treating spraying of seaweed extract with two concentrations 3 or $6 \mathrm{~g}$. $\mathrm{L}^{-1}$ with $2 \mathrm{ml}$. $\mathrm{L}^{-1}$ of nutrient solution and they did not differ significantly between them, as it reached $\left(150.30\right.$ and $\left.165.16 \mathrm{dm}^{2}\right)$, respectively. The lowest value of leaf area was $\left(101.72 \mathrm{dm}^{2}\right)$ when not spraying both solutions (the comparison). Nutrient solution at a concentration of $4 \mathrm{ml}$. $\mathrm{L}^{-1}$ with no spray with seaweed extract had gave the highest significant values of chlorophyll leaf content and it was (54.267 SPAD) while it decreased to (39.933 SPAD) when comparing treatment (not spraying with both solutions). The treatment of spraying seaweed extract was superior to a concentration of $6 \mathrm{~g}$. $\mathrm{L}^{-1}$ with $4 \mathrm{ml} . \mathrm{L}^{-1}$ is a significantly nutritious solution by giving the highest value of the percentage of dry matter to the plant $(13.413 \%)$ compared to the rest of the treatments except the treatment of spraying the seaweed extract by $6 \mathrm{~g} \mathrm{~L}^{-1}$ with 2 or $4 \mathrm{ml}$. $\mathrm{L}^{-1}$ nutrient solution, while the percentage of plant dry matter decreased to $(7.777 \%)$ when comparing treatment (not spraying with both solutions).

Table 1. The effect of Hortiphyte and seaweed extract (Stymulant forte) on the vegetative growth characteristics of the Safari variety

\begin{tabular}{ccccccc}
\hline $\begin{array}{c}\text { Stymulant } \\
\text { forte } \\
\text { m. L- }{ }^{-1}\end{array}$ & $\begin{array}{c}\text { Stymulant } \\
\text { forte } \\
\text { g. L- } \mathbf{1}^{-}\end{array}$ & $\begin{array}{c}\text { Stem } \\
\text { height } \\
\text { cm }\end{array}$ & $\begin{array}{c}\text { Number of } \\
\text { air-stem. } \\
\text { Plant }^{-1}\end{array}$ & $\begin{array}{c}\text { Leaf area } \\
\left(\mathbf{c m}^{2}\right)\end{array}$ & $\begin{array}{c}\text { Chlorophyll } \\
\text { (SPAD) }\end{array}$ & $\begin{array}{c}\text { Plant dry } \\
\text { matter\% }\end{array}$ \\
\hline \multirow{2}{*}{0} & 0 & $72.00 \mathrm{~cd}$ & $3.500 \mathrm{c}$ & $101.72 \mathrm{a}$ & $39.933 \mathrm{~d}$ & $7.777 \mathrm{~d}$ \\
& 3 & $68.00 \mathrm{~d}$ & $4.750 \mathrm{~b}$ & $130.25 \mathrm{c}$ & $51.133 \mathrm{ab}$ & $9.337 \mathrm{c}$ \\
& 6 & $79.00 \mathrm{a}$ & $3.666 \mathrm{c}$ & $140.71 \mathrm{~b}$ & $53.600 \mathrm{a}$ & $12.300 \mathrm{a}$ \\
2 & 0 & $77.66 \mathrm{~b}$ & $5.250 \mathrm{a}$ & $121.49 \mathrm{~d}$ & $51.000 \mathrm{a}$ & $\mathrm{d} 8.207 \mathrm{c}$ \\
& 3 & $76.33 \mathrm{~cd}$ & $4.417 \mathrm{~b}$ & $150.30 \mathrm{a}$ & $48.000 \mathrm{c}$ & $8.713 \mathrm{~cd}$ \\
& 6 & $76.33 \mathrm{bc}$ & $5.667 \mathrm{a}$ & $165.16 \mathrm{a}$ & $51.467 \mathrm{ab}$ & $11.180 \mathrm{ab}$ \\
4 & 0 & $73.66 \mathrm{c}$ & $3.833 \mathrm{c}$ & $118.57 \mathrm{de}$ & $54.267 \mathrm{a}$ & $8.877 \mathrm{~cd}$ \\
& 3 & $81.00 \mathrm{a}$ & $4.917 \mathrm{~b}$ & $130.79 \mathrm{c}$ & $50.767 \mathrm{~b}$ & $10.100 \mathrm{bc}$ \\
Stymulant & 6 & $82.33 \mathrm{a}$ & $4.667 \mathrm{~b}$ & $146.66 \mathrm{~b}$ & $38.400 \mathrm{~d}$ & $13.413 \mathrm{a}$ \\
forte & 0 & $84.22 \mathrm{~b}$ & $4.175 \mathrm{~b}$ & $119.85 \mathrm{c}$ & $50.394 \mathrm{a}$ & $11.959 \mathrm{~b}$ \\
& 3 & $84.55 \mathrm{~b}$ & $4.358 \mathrm{ab}$ & $166.89 \mathrm{a}$ & $51.311 \mathrm{a}$ & $12.006 \mathrm{~b}$ \\
& 6 & $90.06 \mathrm{a}$ & $4.727 \mathrm{a}$ & $145.20 \mathrm{~b}$ & $52.644 \mathrm{a}$ & $14.068 \mathrm{a}$ \\
Hortiphyte & 0 & $83.66 \mathrm{~b}$ & $4.053 \mathrm{~b}$ & $160.26 \mathrm{a}$ & $49.544 \mathrm{a}$ & $12.136 \mathrm{a}$ \\
& 2 & $88.16 \mathrm{a}$ & $4.788 \mathrm{a}$ & $134.68 \mathrm{~b}$ & $54.067 \mathrm{a}$ & $12.201 \mathrm{a}$ \\
& 4 & $87.00 \mathrm{a}$ & $4.419 \mathrm{a}$ & $137.00 \mathrm{~b}$ & $50.739 \mathrm{a}$ & $13.136 \mathrm{a}$ \\
\hline
\end{tabular}

\section{Crop yield characteristics}

It is noted from Table (2) that spraying seaweed extract significantly affected all crop yield characteristics compared to the non-spray treatment. The spray treatment was significantly and superior to $6 \mathrm{~g}$. $\mathrm{L}^{-1}$ compared to the majority of the treatments in the average number of tubers, the yield of one plant and the percentage of dry matter for tubers $\%$, where it reached (13.111 tuber. Plant ${ }^{-1}, 1.63 \mathrm{~kg}$ and $16.127 \%$ ), respectively. The two spray treatments were superior to 3 or $6 \mathrm{~g}$. $\mathrm{L}^{-1}$ were significant on the treatment of non-spraying in terms of the average weight of tuber and total yield, and they did not differ significantly between them. The results of the same table indicate that spraying feed solution with 2 or 4 concentrations. $\mathrm{L}^{-1}$ produced the highest significant values for the average weight of the tuber, the yield of one plant, the percentage of dry matter for tubers and the total production per unit area compared to the no-spray treatment, the increase was of $(11.11 \mathrm{~kg}, 11.68$ $\mathrm{kg}, 7.43 \%$ and 11.54 tons. ha $\left.{ }^{-1}\right)$, respectively. However, there was no significant effect from the no-spray treatment in terms of the average number of tubers. plant ${ }^{-1}$. It is evident from the 
interaction factors between seaweed extract and the nutrient solution, the treatment of spraying the seaweed extract by $6 \mathrm{~g}$. $\mathrm{L}^{-1}$ with $2 \mathrm{ml}^{-1} \mathrm{~L}^{-1}$ by giving the highest values in the average number of tubers amounted to (13.417 tuber. plant ${ }^{-1}$ ) compared to the majority of treatments except for the treatment of no spraying or spraying with $6 \mathrm{~g}$. $\mathrm{L}^{-1}$ of seaweed extract with $2 \mathrm{ml}^{-\mathrm{L}^{-1}}$ feed solution or not sprayed with feed solution with $6 \mathrm{~g}$. $\mathrm{L}^{-1}$ seaweed extract. The treatment of spraying seaweed extract was highly significant at a concentration of $6 \mathrm{~g}$. $\mathrm{L}^{-1}$ with spraying with $2 \mathrm{ml}$. $\mathrm{L}^{-1}$ of nutrient solution in the tuber weight ratio which reached $0.136 \mathrm{~kg}$ compared to all interference treatments except for spraying treatment with 3 g. $\mathrm{L}^{-1}$ seaweed extract with nutrient solution of $4 \mathrm{ml}$. $\mathrm{L}^{-1}$. The lowest value of the average weight of tuber was $(0.097 \mathrm{~kg})$, was with comparing treatment (not spraying both solutions), while the treatment of spraying seaweed extract at a concentration of $6 \mathrm{~g}$. $\mathrm{L}^{-1}$ with $4 \mathrm{ml}$. $\mathrm{L}^{-1}$ was the highest yield of one plant $(1.61 \mathrm{~kg})$ and was significantly superior compared to most treatments, except for spraying treatment with $6 \mathrm{~g}$. $\mathrm{L}^{-1}$ seaweed extract with no spray or $4 \mathrm{ml}$. $\mathrm{L}^{-1}$ nutritional solution. The lowest value for the yield of one plant was when no spraying with both solutions (the comparison), where it reached $(0.97 \mathrm{~kg})$. The comparison treatment was significantly superior by giving the highest percentage of dry matter to the tubers $(17.133 \%)$ compared to some treatments and did not differ from the treatments of spraying the nutrient solution at a concentration of $4 \mathrm{ml}$. $\mathrm{L}^{-1}$ with seaweed extract and three concentrations, and with spraying of the nutrient solution at a concentration of $2 \mathrm{ml}$. $\mathrm{L}^{-1}$ and non-spraying with seaweed extract. The lowest value for the percentage for tubers dry matter was $(12.833 \%)$ when treating spraying with 3 g. $\mathrm{L}^{-1}$ seaweed extract with $2 \mathrm{ml}$. $\mathrm{L}^{-1}$ nutritional solutions. The treatment of spraying seaweed extract was produced at a concentration of $6 \mathrm{~g}$. $\mathrm{L}^{-1}$ with spraying $4 \mathrm{ml} . \mathrm{L}^{-1}$ feed solution, the highest significant value of the average production unit per area reached (85.965 tons. ha $^{-1}$ ) compared to all interference treatments except spraying treatments of seaweed extract by $6 \mathrm{~g}$. $\mathrm{L}^{-1}$ with without spraying or spraying with $2 \mathrm{ml} . \mathrm{L}^{-1}$ of a nutrient solution. The lowest value of production per unit area as a comparison treatment (not spraying both solutions) was 51.813 tons. ha $^{-1}$. It is noted from the results of Table (1) an increase in the average length of the stem. plant ${ }^{-1}$, chlorophyll, and the percentage of plant dry matter\%, as it was significantly affected by spray treatments with seaweed extract, as spray treatment was characterized by 6 g.L. $\mathrm{L}^{-1}$ was significant from the rest of the transactions. This was explained by Ramya et al., (2017) to the role of nutrients and vitamins contained in the seaweed extract and the role of cytokines and amino acids of all kinds in the manufacture and production of carbohydrates and chlorophylls and their impact on plant growth in general. Doss et al. (2015) agreed that spraying brawn seaweed at a concentration of $0.75 \%$ resulted in a significant increase in the average length of the plant, the number of aerial stems and the dry percentage of the plant, and the results matched with Nawar and Sabreen (2014) when spraying the seaweed extract (Algae) 600 at a concentration $(15 \% \mathrm{~W} /$ volume) and the reason was attributed to the role of major and minor elements present in this extract in addition to containing natural hormones such as oxins, gibberelins and cytokines with concentrations that lead to improving and increasing vegetative growth. These results were consistent with the findings of EL-Gizawy (2000), (Turan and Kose, 2004), Al-Jabouri (2009), and Al-Tamimi (2009). As for the effect of spraying with a nutrient solution, spraying was given in concentrations of 2 or $4 \mathrm{ml}$. $\mathrm{L}^{-1}$ was the highest significant mean in the average length of the stem and the number of aireal stems, these results matched with the findings of A-Ebadi $\boldsymbol{e t}$ al. (2007) and Al-Fadhli (2011). These findings may due to nutrient solution containing nutrients, including nitrogen, phosphorous, manganese and zinc, which have an important role in building the plant at all stages of growth, as nitrogen has an important role in stimulating ammonium ions $\mathrm{NH}_{4}+$ as a result of stimulating ammonia $\mathrm{NH}_{3}$ and thus increasing nitrogen.

Meanwhile, zinc plays an important role. It works to stimulate protein building and activate phosphate transport enzymes (Al-Sahaf, 1989) and nitrogen has an important role in photosynthesis as it enters with manganese in the formation of a chlorophyll molecule and thus encourages the division and elongation of cells (Abu Dhahi and Yunus, 1988 and Hassan, 1989). 
In addition, the element zinc has an important role in plant growth, especially the vegetative system, as it enters in many enzymes, including dehydrogennises, aldolas and isomerases, and to its role in the synthesis of the amino acid tryptophan, which is the initiator of the synthesis of oxins that have an effective role in cell division and expansion (Abu Dhahi and
Yunus 1988), and energy production, Moysavi et al. (2007) as well as its role in nitrogen uptake and starch formation, Havlin et al. (2005) and Asi (2017), in addition to the important role of $\mathrm{Mn}$ and its entry into the synthesis of some enzymes responsible for photosynthesis of chlorophyll in the plant, ALFadhly (2016).

Table 2. Effect of Hortiphyte and Seaweed extract (Stymulant forte) on the yield of Safari potato plant

\begin{tabular}{ccccccc}
\hline $\begin{array}{c}\text { Hortiphyte } \\
\text { m.L-1 }\end{array}$ & $\begin{array}{c}\text { Stymulant } \\
\text { forte } \\
\text { g. L- }{ }^{1}\end{array}$ & $\begin{array}{c}\text { Average } \\
\text { number of } \\
\text { tubers per } \\
\text { plant }\end{array}$ & $\begin{array}{c}\text { Tuber } \\
\text { weight } \\
\text { ratio } \\
\text { kg }\end{array}$ & $\begin{array}{c}\text { Average } \\
\text { yield of } \\
\text { one plant } \\
\text { kg }\end{array}$ & $\begin{array}{c}\text { Tubers dry } \\
\text { matter\% }\end{array}$ & $\begin{array}{c}\text { Total yield } \\
\text { ton. } \mathbf{h}^{-}\end{array}$ \\
\hline \multirow{2}{*}{0} & 0 & $10.000 \mathrm{bc}$ & $0.097 \mathrm{~d}$ & $0.97 \mathrm{e}$ & $17.133 \mathrm{c}$ & $51.813 \mathrm{e}$ \\
& 3 & $10.417 \mathrm{~b}$ & $0.109 \mathrm{c}$ & $1.12 \mathrm{de}$ & $13.500 \mathrm{c}$ & $60.218 \mathrm{de}$ \\
& 6 & $11.030 \mathrm{a}$ & $0.130 \mathrm{a}$ & $1.42 \mathrm{a}$ & $16.300 \mathrm{~b}$ & $75.893 \mathrm{a}$ \\
2 & 0 & $13.250 \mathrm{a}$ & $0.105 \mathrm{c}$ & $1.38 \mathrm{~b}$ & $19.167 \mathrm{a}$ & $73.653 \mathrm{~b}$ \\
& 3 & $10.083 \mathrm{bc}$ & $0.125 \mathrm{~b}$ & $1.26 \mathrm{c}$ & $12.833 \mathrm{c}$ & $67.636 \mathrm{c}$ \\
& 6 & $11.333 \mathrm{a}$ & $0.136 \mathrm{a}$ & $1.53 \mathrm{a}$ & $15.633 \mathrm{bc}$ & $82.067 \mathrm{a}$ \\
4 & 0 & $9.167 \mathrm{c}$ & $0.117 \mathrm{~b}$ & $1.07 \mathrm{c}$ & $16.267 \mathrm{a}$ & $57.098 \mathrm{c}$ \\
& 3 & $11.000 \mathrm{~b}$ & $0.132 \mathrm{a}$ & $1.43 \mathrm{~b}$ & $14.800 \mathrm{a}$ & $76.587 \mathrm{~b}$ \\
& 6 & $13.417 \mathrm{a}$ & $0.120 \mathrm{~b}$ & $1.61 \mathrm{a}$ & $14.667 \mathrm{a}$ & $85.965 \mathrm{a}$ \\
Stymulant & 0 & $10.819 \mathrm{~b}$ & $0.121 \mathrm{~b}$ & $1.29 \mathrm{c}$ & $15.844 \mathrm{~b}$ & $69.229 \mathrm{~b}$ \\
forte & 3 & $11.733 \mathrm{~b}$ & $0.125 \mathrm{a}$ & $1.44 \mathrm{a}$ & $14.611 \mathrm{~b}$ & $77.133 \mathrm{a}$ \\
& 6 & $13.111 \mathrm{a}$ & $0.126 \mathrm{a}$ & $1.63 \mathrm{a}$ & $16.127 \mathrm{a}$ & $87.390 \mathrm{a}$ \\
& 0 & $11.800 \mathrm{a}$ & $0.117 \mathrm{~b}$ & $1.37 \mathrm{~b}$ & $14.800 \mathrm{~b}$ & $73.356 \mathrm{~b}$ \\
Hortiphyte & 2 & $11.405 \mathrm{a}$ & $0.130 \mathrm{a}$ & $1.47 \mathrm{ab}$ & $15.883 \mathrm{a}$ & $78.574 \mathrm{a}$ \\
& 4 & $12.458 \mathrm{a}$ & $0.124 \mathrm{a}$ & $\mathrm{a} 1.53 \mathrm{a}$ & $15.900 \mathrm{a}$ & $81.822 \mathrm{a}$ \\
\hline
\end{tabular}

The increase in the qualitative and quantitative yield characteristics in Table (2) may be explained by the significant increase in most characteristics of vegetative growth, which was reflected positively in yield characteristics. Moreover, elements of manganese and zinc, as mentioned previously, they have a great role of nutrients in plant growth, agreed by Taheri et al. (2012). The increase in the average weight of tuber, the yield of one plant, the percentage of dry matter of tubers and the total yield were consistent with AL-Fadhly (2016), Arafa et al., (2012) and Pramanick et al. (2018) and the results were consistent with what Pramanick et al. (2017), Taha (2011) that seaweed extract (Alga 600) has an important role in achieving nutritional balance in plant growth due to it contains GA3 and GA7 in addition to the nutrients that help improve photosynthesis, metabolic processes and nutrient absorption from calcareous soils (Eris et al., 2008).

\section{REFRENCES}

Abo-Arab, R. B.; Helal, R. M. and Al-Aidy, Y.A. (1998). Bioresidual Activity of Certain Oils and Plant Extraction Some Stored Grain Insects in Relation with Quality of Wheat Grain. J. Agric. Sci. Mansoura Univ., 23: 56415653.

A-Ebadi, A.; Hassanzadeh, G.; Dehdar, B. and Asadimanesh, H. (2007). Evaluation of zinc Micronutrient Effects on yield and some characteristics of two potato cultivar.www.zinc.crop.org.

Al - Fadhly, Jawad T. M. (2016). Response of Potato (Solanum Tuberosum L.) to Foliar Application of Zinc and Manganese Which 
Fertilized by Organic Fertilizer. Iosr J0 Agric. and Veterin. Sci., 9(4): 87-91.

Arafa, A.A.; M. Hussien, S. F. and Hager, S. G. Mohamed (2012). Response of tuber yield quantity and quality of potato plants and its economic consideration to certain bioregulators or efective microrganisms under potassium fertilization. J. Plant Production, Mansoura Univ., 3 (1): 131-150.

Doss, M. M.; El-araby, S. M.; Abd El-fattah, M. A. and Helaly, A. A. (2015). The impact of spraying with different concentrations of seaweed extract under different levels of mineral npk fertilizers on sweet potato (Ipomoea batatas L.) Plants. Alex. J. Agric. Res., 60 (3): 163-172.

El-Gizawy, N.Kh.B. (2000). Response of maize (Zea mays,L.) to nitrogen and manganese fertilization. Ph.D. Thesis, Fac. Agric. Moshtohor, Benha Univ., Egypt.

Elia, A and Santaria, P (1997). Produsing nitrate-free endive heads: effect of nitrogen from on growth, yield and composition of endive: J. Amer. Soc. Hort. Sci., 122: 140-145.

Eris, A.; Sirritepe, H. O. and Sirritepe, N. (2008). The effect of seaweed (Ascophyllum nodosum) Extract on yield and quality criteria in pipers Acta Horti. (ISHS), 412: 733-737.

F.A.O. (2019). FAO STAT (Retivaldate, January 5, 2019).

F.A.O. Food and Agricultural Organization. (2008) Yearbook of fishery statistics, Rome, (98), 1-2.

Havlin, J. L.; Beaton, J. D.; Tisdale, S. L. and Nelson, W.L. (2005). Soil Fertility and Nutrient Management. 7th Edition. Pearson Prentice Hall. Upper Saddle River, NJ.

Jemison, J. and Williams, M. (2006). PotatoGrain Study Project Report Water Quality Office. University of Maine, Cooperation Extension. http://www.umext.main.edu.

Jensen, E. (2004). Seaweed Fact or Fancy. From the organic broad caster, published by mosses the Midwest organic and sustainable education from the broadcaster, 12 (3): 164170.

Minnotti, P.L.; Halseth, D.E. and Sieczka, J.B. (1994). Chlorophyll measurement to assess the nitrogen status of potato varieties. Hortscience, 29(12): 1497-1500.

Mousavi, S. R.; Galavi, M. and Goudarz, A. (2007). Effect of Zinc and Manganese Foliar Application on Yield, Quality and Enrichment on Potato (Solanum tuberosum L.). Asian J. Plant Sci., 6: 1256-1260.

Nawar, Dalia A.S and Sabreen Kh. A. Ibraheim (2014). Effect of Algae Extract and Nitrogen Fertilizer Rates on Growth and Productivity of Peas. Middle East J. Agric. Res., 3(4): 1232-1241.

Pramanick, B; Koushik, B.; Mahapatra, B. S.; Arup G. and Sudeshna, K. (2017). Growth, yield and quality improvement of potato tubers through the application of seaweed sap derived from the marine alga Kappaphycus alvarezii. J. Appl. Phycology, 29: 3253-3260.

Pramanick, B.; Koushik, B.; Dibakar, G. and Bera, P.S. (2018). influence of foliar application seaweed (kappaphycus and gracilaria) saps in riceoryza sativa)-potato (solanum tuberosum L.) blackgram (vigna mungo) sequenceindian. J. agron., 63 (1): 7-12.

Ramya. S; Sivasangari, N.; Vijayanand, N. and Rathinavel, S. (2017). Foliar application of liquid biofertilizer of brown alga stoechospermum marginatum on growth, biochemical and yield of solanum melongena int $\mathrm{j}$ recycl org waste agricult, 4:167-173.

Strik,W. A.; Arthur, G. D.; Lourens, A. F.; Novak, O.; Strnad, M. and Vanstaden, J. (2004). Changes in cytokinin and auxin concentrations in sea weed concentrates when stored at an elevated temperature. J. Appl. Phycology, 16: 31-39.

Taha, Z. S. (2011). Effect of humic acid and seaweeextracts on growth and yield of potato plant (solanum tubersum L.) desiree cv . mesopotamia j. of agric (issn 1815-316x) vol. (39) no (2) hort. dept., college of agric., Duhok Univ., Iraq.

Taheri, N.; Sharif-Abad, H.H.; Yousefi, K. and Roholla-Mousavi, S. (2012). Effect of compost and animal manure with phosphorus and zinc fertilizer on yield of seed potatoes. J. Soil Sci. Plant Nutrition, 12 (4): 705-714. 
Turan, M. and Köse, C. (2004). Seaweed extracts improve copper uptake of grapevine. J. Acta Agriculturae Scandinavica, Section B-Soil \& Plant Science. 54: 213-220.

Verkeij, F. N. (1992). seaweed extract in agriculture and horticulture. Review of biological horticulture, 8: 309-324.

أبو ضـاحي، يوسف محمد. ومؤيد احمـ اليونس (1988). دليل تغذية النبات. جامعة بغداد. وزارة التعليم العـالي و البحث

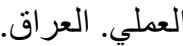

تكنلوجيـا زراعـة البطاطـا (2005). وزارة الزراعـة، الهيئسة العامة للإرشاد و التعاون للزر البطاط. نشرة ارشادية رقم9.

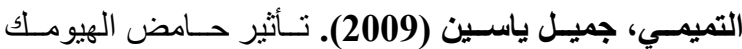

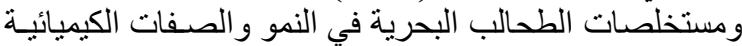

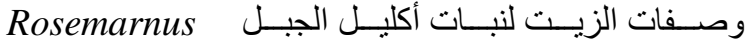
officinalis كلية التربية، جامعة تكريت، علوم البنات، ص:17-17.

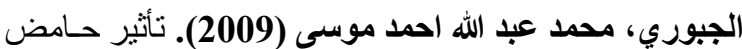

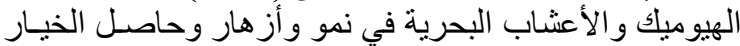

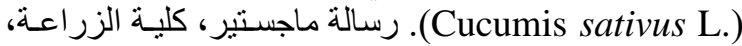
جامعة تكريت، وزارة التعليم العالي و البحث العلمي، جمهورية التراعة

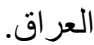

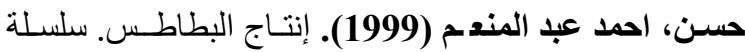

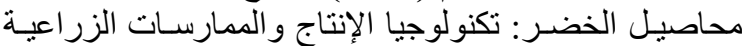

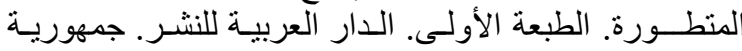
مصر العربية. 446 صفحة.

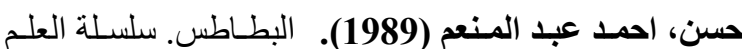

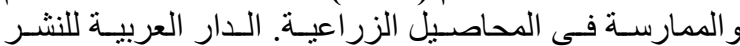

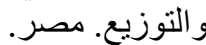

داؤد، زهير عز الداين وعبد الوهـاب حمدي قاستم (2003).

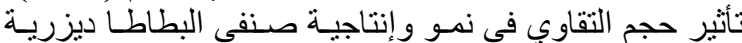
وعجيية. المجلة العر اقية للعلوم الزراعية المجلد 4 العدد (3): .36-29

الصحاف، فاضـل حسين (1989). تغذيـة النبـات النطبيقي. جامعة بغداد. وزارة التعليم العالي و البحث العلمي. العراق.

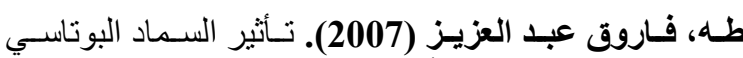

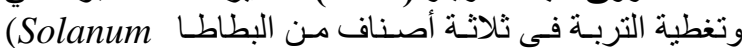

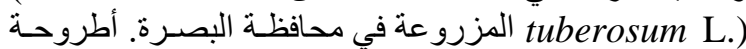

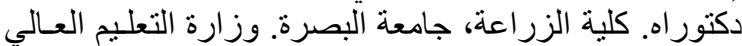
و البحث العلمي. جمهورية العراق.

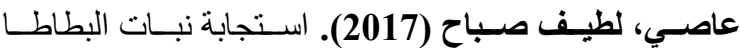

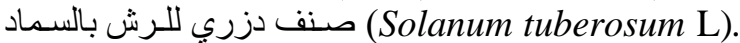

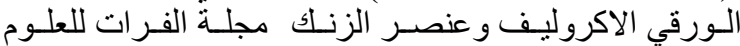

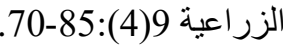

العبيدي، عبد المنعم سعدالله خليل حياوي (2005).

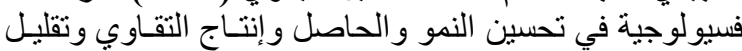

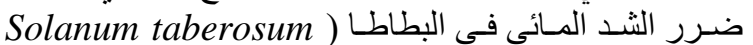

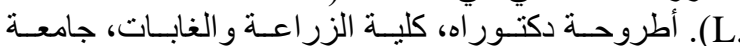
الموصل، وزارة التعليم والبحث العلمي، جمهورية العراقية العزات
الفضـلي، جــواد طــه محمــود (2011). تــأثير التسـميد

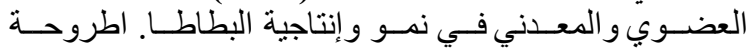
دكتور اه كلية الزر اعة. جامعة بغداد.

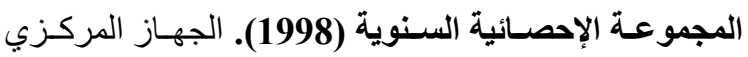

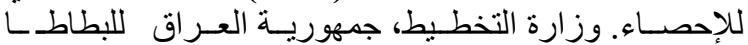

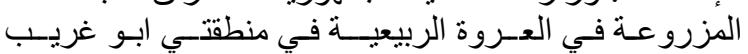

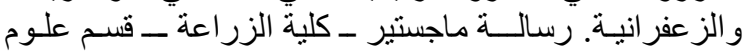

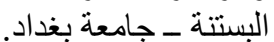

مديرية زراعة نينوى (2009). إحصـائية عن إنتاج البطاطـا في محافظة نينوى، مديرية زر اعة نينوى (20نية التخطيط و المتابعـة.

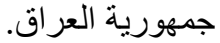

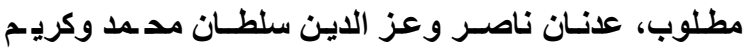

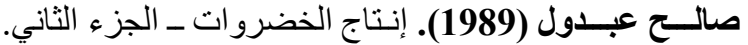

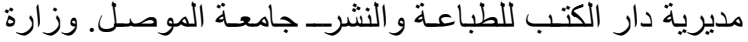
التعليم العالي و البحث العلمي - جمهورية العر اق.

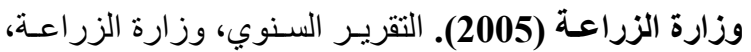
دائرة الإحصاء و المتابعة، جمهورية العراق. 